\title{
Q
}

ISSN 2278 - 0211 (Online)

\section{Barriers to Uptake and Use of Added Value Mobile Money Products by the Lesser off Segments in Kenya}

\author{
Dr. Martina Mulwa \\ Lecturer, School of Journalism and Mass Communication, University of Nairobi, Kenya \\ Samuel Ngigi \\ Lecturer, School of Journalism and Mass Communication, University of Nairobi, Kenya
}

\begin{abstract}
:
The successful uptake and use of key mobile money transfer services in Kenya has seen a tremendous growth in innovative mobile money products aimed at extending formal financial services to the lesser off segments in society. Despite the convenience associated with these products and the fact that access to financial services has increased, studies point to the fact that use is additive in nature and the lesser off segments remain excluded. This paper seeks to establish barriers encountered by the lesser off segments and further discuss suitable policy and regulation frameworks to enhance transformative use of the products by the unbanked populations.
\end{abstract}

Keywords: Added value mobile money products, lesser off segments, regulation, policy

\section{Introduction}

Mobile money systems have characterized the execution of monetary transactions in Kenya in recent years. As of December 2013 (CCK, 2014) 26.1 million subscribers were active in various forms of mobile money transactions among them money transfers, mobile banking, payment systems or other forms. Populations excluded from formal financial services in Kenya have been the target through agency networks whose number stood at 93,689 as of December 2013 and mobile phone subscribers whose number increased from 29.2 in 2012 to 31.03 in 2013 (CCK, 2013). Driving the exponential transformation is the acute lack of formal financial services particularly in rural areas, in addition mobile money products on offer have been designed to address needs that target poor and marginalized populations. For this reason, even populations that were in urban areas but excluded from existing financial services due to unsuitable models (Mulwa \& Ndati, 2013) have found mobile money systems friendly and accommodative of their specific needs. Such needs include convenience of operating hours, amounts of transactions, any time anywhere access, privacy, intermediation among others. However, these perceived benefits of mobile money risk going to the drain if the statistics of the actual relevance to financial inclusion is anything to go by. According to Global financial data, $75 \%$ of Kenyan adults have a bank account, $63 \%$ of these being mobile money accounts (intermedia) however while $93 \%$ of the richest are formally included $55 \%$ of the poorest are completely excluded from formal and informal financial services.

\subsection{Problem Statement}

Money transfer models in Kenya have remained fairly stable since the inception of m-pesa in 2007, these has seen financial inclusion models emerge seeking to ride on these services to provide solutions to a wide range of user needs and more specifically reaching the unreached financially. Among them are savings and credit platforms like M-ASCA (Mobile Accumulating Savings and Credit Association) that seek to streamline operations of the informal sector dominated by Rotating savings and credit associations (ROSCAs) and accumulating savings and credit associations (ASCAs) by automating the entire processes that begin at registration through saving borrowing getting guaranteed and general management of user accounts. According to FSD Kenya (2009), a total volume of Kshs 65 billion is intermediated through ROSCAs and ASCAs on an annual basis. Others target payment of services, the most popular being lipa na m-pesa by safaricom, a product that has proliferated practically every form of payment in Kenya including government services like renewal of driving licenses, payment of fines in courts among many others. Delivery of these products has been met with an outcry from various stakeholders in regard to exorbitant tariffs in money transfer services, lipa na m-pesa tariffs (CGAP, 2015), coexistence of the telecom and the banking sector as seen in the recent outcry by the Equity Bank CEO, Dr. James Mwangi over the increase of charges in the transfer of funds from m-pesa to bank accounts (Frankline Sunday, 2015), differentiation of services; in that those who wish to save 
money are lamped together with those who wish to pay for services, a great barrier to savings since ordinarily one is not charged to save money. In addition, despite the convenience associated with use, there are no laws in place to mitigate risks of use and customers suffer without recourse in the hands of emergent fraudsters who range from ordinary criminals to staff of the service providers (Vincent Matinde (2014).

\subsection{Objectives}

This paper aims at dissecting the issues surrounding added value models, gaining an in depth understanding of target populations, product designs, challenges faced by service providers of these products, mitigating strategies in policy and regulation and ultimately a suitable model for value addition.

The specific objectives of this paper therefore were to:

- Underscore the challenges facing added value products aimed at financial inclusion of the lesser off segments in Kenya

- Discuss the conditions of access of added value mobile money products and impact on actual use

- Interrogate existing policies and regulations and the role they play in creating an enabling environment for beneficial use of the products by lesser of segments in society

\section{Literature Review}

Models targeting the lesser off segments in society have remained elusive despite the various interventions evident in the market. The Micro finance model that was perceived as magic bullet of the 1070s has come under intense criticism (Adam \&Von Pishke 1993, Gulli 1998) with critiques questioning the value addition in the exorbitant cost of credit, debt as an effective tool for helping the poor to enhance their economic condition and the usefulness of the Grameen model itself. A study done on the impact of microfinance on poverty reduction (Joy M. Kiiru, 2007) concluded in particular that providing affordable financial services to the rural population still remains to be an important component of development strategy. With emphasis on the role played by the poor themselves in alleviating their poverty through sustainable means.

Mobile money platforms can be instrumental in financial inclusion if challenges facing the industry could be addressed as these are used daily and weekly indicating a higher level of importance in people's daily lives and a stronger connection with the informal flows (CBK \& FSD Kenya 2013). Added value mobile money products are those that go beyond money transfer. Money transfer services such as m-pesa, airtel money or orange money provide the infrastructure necessary for financial actions but in themselves do not constitute financial inclusion. The infrastructure to greater use of mobile money therefore provides a breakthrough to both access and convenience for the unbanked populations in Kenya.

Headline figures from survey data place Kenya at the top of the financial inclusion index both regionally and globally. Data from the last Global Findex survey shows that 75\% of Kenyan adults have a formal account that allows them to save, send or receive money. Much of Kenya's success has occurred in the last 10 years and has been driven by supply side innovations such as M-PESA, M-Shwari and agency outlets (FSD, 2015). With 68,000 bank and mobile money agents spread across the country, nearly three quarters of the population now live within 3 kilometers of a financial sector access point, showing that Kenya has transcended the access frontier. Riding on the mobile payments platform M-PESA, new innovations in mobile banking such as M-Shwari, KCB M-PESA and Equitel, have delivered bank accounts to approximately 10 million Kenyans, who can now access savings and loans. While these products are convenient to the unbanked populations, their offer and design is limiting to the unbanked, being bank led, one has to meet certain conditions, secondly the interest rates per month are very high and it's rolled monthly. In addition, the amounts given are small and may not be useful for any investment. studies indicate that despite the hype over the role money transfer services play in Kenya 83\% of transactions of over Ksh 1000 are still in cash (FSD Diaries) reason being the high transaction costs on mobile usage.

While $93.2 \%$ of the richest are formally included, 55.3\% of the poorest are completely excluded from formal and informal financial services (FSD, 2015). Reasons cited for the disparity was cost of maintaining an account, lack of funds to save at the bank as well as an agency infrastructure that was concentrated on densely populated areas therefore excluding marginalized and poor populations especially in rural areas. In addition, this exclusion goes further to reinforce the fact that mobile money in itself is not synonymous with financial inclusion but is a part of the process towards financial inclusion as it increases the opportunity to access formal financial services. Mobile Money lending by most availed mobile money platforms target salaried people for easy recovery. Loans through Models like M-Shwari are so minimal for any meaningful undertaking. Furthermore, the criterion for the loan ceiling is at the discretion of the Mobile Network Operators. At the end these providers declare huge profit margins ${ }^{1}$ whereas the status quo of the users remains at a standstill if not worse.

While the poor are known to save more than they borrow through the informal saving self-help groups (Zollman, J. (2014), there is a risk of losing the opportunity to add value to the existing rich informal ecosystem if mobile money service providers focus on short-term gratifications of quick financial gains as opposed to the huge gap at the BOP that could guarantee them long term and worthwhile undertaking. Savings and credit platforms designed with the needs of the lesser off in mind to conveniently submit savings, borrow, guarantee, repay and manage user accounts at ease exist in Kenya. The predicament such models find themselves in is that tariffs imposed on the saving channels may end up missing out on the gap they were made to address.

${ }^{1}$ Safaricom declared a profit after tax of Ksh 38.1 billion a growth of 19.6\% in March 2016 at the investors ,briefing held at the Michael Joseph centre in Nairobi 
Tariffs by most Mobile Network Providers in Kenya are punitive considering that members are charged to submit savings to their member accounts also known as pay bill accounts as Customer to Business transactions (C2B). The same customer is charged when a loan is disbursed from the Business to Customer (B2C) account or when they want to withdraw money from the $\mathrm{B} 2 \mathrm{C}$ account. From the $\mathrm{B} 2 \mathrm{C}$ to the member virtual wallet account a tariff another tariff is applied. Once in the customer virtual wallet account the member is again charged for withdrawing from an outlet where the normal withdrawal tariffs apply.

M-ASCA in Kenya is a financial product and service delivery innovation that provides options for low income people to meet their competing financial needs by conveniently converging customers and their social networks virtually to nurture their saving culture in order to enable them invest in the advancement of their livelihoods. With questions glaring as to the impact of Microfinance models in poverty reduction and consequently the revelation that mobile money use as of now does not contribute to financial inclusion and neither does it contribute to better livelihoods for the lesser off segments, there is need for a deliberate policy and regulatory intervention to grow added value mobile money products by addressing barriers to effective transformative use of mobile money by the lesser off segments in Kenya.

\subsection{Theories Informing the Study}

This study uses Technology Readiness Index and Technology Acceptance Model (TRAM) as an integrated concept as proposed by Preben Godoe \& Trond Stillaug Johansen. The study posits that personality dimensions in TRI and the main elements proposed in TAM influence the actual use of technology.

\subsection{Technology Readiness Index}

Technology readiness (TR) refers to the people's propensity to embrace and use new technologies to accomplish goals in home life and at work (Parasuraman, 2000). It is a combination of positive and negative technology-related beliefs that are assumed to vary among individuals and therefore influence the person's predisposition to availed technology in their context. Diversity among individuals cut across user attributes that include age, gender, educational background, monthly income among others. Parasuraman categorizes these beliefs into four dimensions i.e. optimism, innovativeness, discomfort, and insecurity (Parasuraman, 2000).

Optimism occurs when people belief that technology leads to increased control, flexibility, and efficiency in their lives (Parasuraman \& Colby 2001). It occurs when technology availed exhibits relative advantage attributes and therefore likely to add value to their lives. Innovativeness on the other hand measures to what degree individuals perceive themselves as techno savvy or uncontested acceptance of technology use by the society. An example of such is m-pesa in Kenya where although $\mathrm{m}$ pesa is a mobile money transfer service by Safaricom, several government services like renewal of driving licenses can only be paid through the Lipa na m-pesa platform yet m-pesa is not yet gazette as legal tender. In addition, a large percentage of Kenyans accept it as a mode of payment. Discomfort is defined as a perceived lack of control over technology and a feeling of being overwhelmed by challenges despite the fact that one is optimistic (Parasuraman \& Colby 2001. This discomfort could span through challenges experienced in technology use including system failures, exorbitant tariffs and exploitative providers, unfair playing field for competition, in ability to operate technology gadgets effectively, cultural factors that may include gender roles and unsolved concerns of use. Insecurity is defined as distrust of technology and skepticism about its ability to work properly. The distrust could encompass a dynamic perspective to capture issues of apprehensiveness over security of funds as opposed to traditional methods of making payments and doing it oneself, the reliance on confirmation messages for every transaction performed failure of which confusion sets in. Distrust may also be occasioned by the setting of an informal outlet with a not so sophisticated assistant as opposed to the elegant bank set up with professionals handling client's money.

While optimism and innovativeness may persuade one to adopt technology discomfort and insecurity require policy and regulatory intervention. Individuals who are optimistic and innovative are likely to adopt and use technology while discomfort and insecurity will lead to skeptics and delayed uptake and use of technology-based products.

\subsection{Technology Acceptance Model}

Technology Acceptance Model (TAM) proposed by Davis (1989) is an information systems theory that explains how users come to accept and use a technology. It suggests that, when users are presented with a new technology, a number of factors influence their decision about how and when they will use it. TAM consists of two beliefs, perceived utilities and perceived ease of application, which determine attitudes to adopt a new technology (Davis 1989). The attitude towards adoption depicts the prospective adopter's positive or negative orientation/ behavior about adopting a new technology. According to Davis (1989) attitudes towards adoption are determined by relevant internal beliefs and are influenced by factors such as; 1) perceived ease of adoption; 2) apprehensiveness; 3) perceived utilities of technology (extrinsic motivation) and; 4) enjoyment (intrinsic motivation). In addition, individual characteristics like age, qualification, their prior experiences in adopting technology; technology suppliers' commitment; compatibility with existing technology and enhanced value are important factors. Social pressure is also another important factor.

\subsection{Technology Readiness Index and Technology Acceptance Model combined}

The key personality dimensions proposed in TRI which include optimism, innovativeness security and discomfort directly impact on perceived usefulness as well as ease of use. An individual that is optimistic about technology will find it 
more useful and easier to use than less optimistic. On the other hand, innovative people will easily adopt technology because they understand what technology can do for them however they are more critical towards technology and will easily establish pitfalls as they expect technology to fulfill the highest of demands. Insecurity negatively impacts perceived usefulness because if the gratification of use may not be achieved then the usefulness of the technology diminishes. On contrary discomfort does not necessarily affect perceived usefulness but will impact negatively on ease of use. Individuals experiencing challenges of usability, cost, system frustration and other negative attributes in use of a technology may not necessarily discredit the value they can get from use of the system but will in normal circumstances seek to reduce the discomfort in order to accrue the benefits actual of use.

Borrowing from the constructs of the two theories therefore our study model proposes linkages between optimism, innovativeness discomfort and insecurity in TRI with the main constructs in TAM which are perceived ease of use and perceived usefulness whose relationships directly influence the actual use of technology-based products.

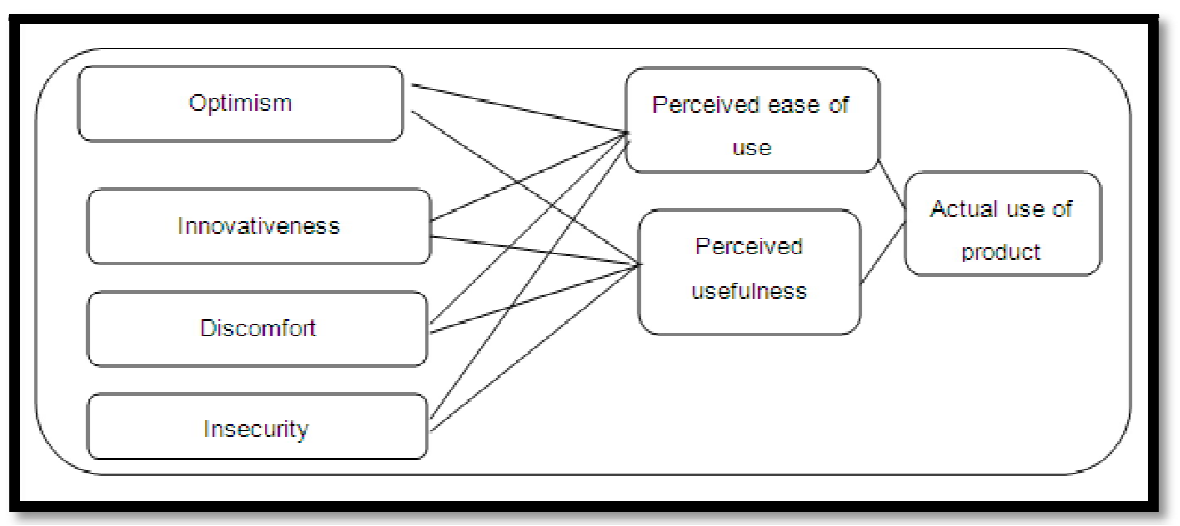

Figure 1: TRI and TAM Combined

\subsection{Conceptualized from Constructs of the Two Theories}

\subsubsection{Relevance to Mobile Money Use}

Kenya tops the globe with the highest number of adults holding a mobile money account according to the global financial inclusion database (World Bank 2015). The value of funds transacted through mobile money in Kenya stood at 2.4 trillion in 2014 (Joshua Masinde 2015) more than the money held as deposits by other financial institutions in Kenya. Furthermore m-pesa is touted as the largest financial institution in the Kenya in terms of volume and banking perspective. Going by the premise mobile money products riding on the current mobile money transfer services seen as convenient, reliable and secure as opposed to cash and other methods attract a lot of good will increasing chances of uptake and use. However, though these products are perceived to be useful, challenges (discomfort) have emerged in use particularly in the way tariffs are designed considering that these are cross-sectoral products with each sector coming with an independent tariff for the combined product. Such has led to an outcry by users terming the cost as double fold. This is not forgetting the supply side dependent on agents who are neither employees of the banks or the mobile telecommunication providers but yet requiring remuneration for services rendered. All these charges are lamped on to the final user of the product. Consequently, the regulators have found themselves trapped by the influx of additive services most of the times experimenting on use before clear guidelines on delivery are put in place. Mobile service providers too have also been caught at crossroads offering services at subsidized tariffs to attract use and denying other platforms held by the public similar packages for similar products without differentiating tariffs made for payments and those meant for savings. However, these products are also not well thought out since interest rates they attract are too high for the financial inclusion cause. In addition, protecting users of mobile money from loss of virtual funds has remained a grave concern. Lose of money by the user or the agent has remained tricky and fraudsters have capitalized on this loophole to deplete gullible mobile money users of their hard-earned cash (Mulwa, 2012)

\section{Methodology}

The study will seek an in depth understanding of the ecosystem surrounding the offer and use of added value products in Nairobi, Kenya. Primary sources will include Mobile network operators, mobile money service providers, mobile money users. The three key MNOs (Safaricom, Equitel and Airtel) will be purposively sampled, PRSPs offering added value services will be purposively sampled. Users will be identified from prsp databases and randomly sampled. The questionnaire was analyzed through SPSS while thematic analysis was used to analyze qualitative data.

\section{Discussion of Findings}

The focus group discussion revealed that users were optimistic of mobile money and all were using mobile money to transfer money and also make payments and savings to their self help and other welfare groups that targeted lesser off 
segments in society. The study also established that the study subjects rarely used the mobile phone to transfer money to their bank accounts as they preferred using bank affiliated agent outlets or visiting the bank branches. This meant that value added mobile money products were basically those that allowed the segment to first load their mobile money wallets and then transfer to a savings account that could form some sort of credit history to enable them get credit to better their lives. All the interviewed and studied groups were registered as self help and their mode of operation was either ROSCA or ASCAs. Unlike in earlier studies where members used to meet regularly to contribute money and then distribute it among themselves, now the members were using the phone to send money to their chairlady who in turn disbursed the lump sum amount to the beneficiary of the contribution. The convenience of the phone allowed members to send money to the chairlady anytime and in small amounts. This helped them avoid getting caught up with days and failing to honor their obligation to the other members. Despite the convenience occasioned by the mobile phone the face to face meetings still persisted. We gathered that such groups were not purely to save and borrow but also took care of other welfare-based needs.

The research established that users saw mobile money as beneficial to their lives despite the challenges they encountered. To them it was convenient. With members saying it was fast efficient reliable and accurate. Mobile money services were applauded for coming in handy during times of emergency and the fact that the service extended to almost all parts of the country including the rural areas. Others also said the mobile money was cheap because one did not need to travel, and it was easy to use. They also claimed that they used mobile money because of the credibility associated with Safaricom and its extensive network claiming that it was in almost all parts of the country and they could transact anytime.

\subsection{The Questionnaire}

The questionnaire was instrumental in confirming the challenges faced in mobile money use as well as in profiling user attributes and the possible relationships through a cross tabulation of key variables in the tool. It targeted those actively using mobile money to either submit savings to a savings account or to make payments.

Majority of those using mobile money were between 18 and 35 years at 74.7\% followed by $36-55$ at $19.7 \%$ the remaining $4.5 \%$ were above 55 years of age. This confirmed that the youth were active in mobile money use and further that mobile money platforms were easy to use across the ages meaning that the designs considered the usability before form.

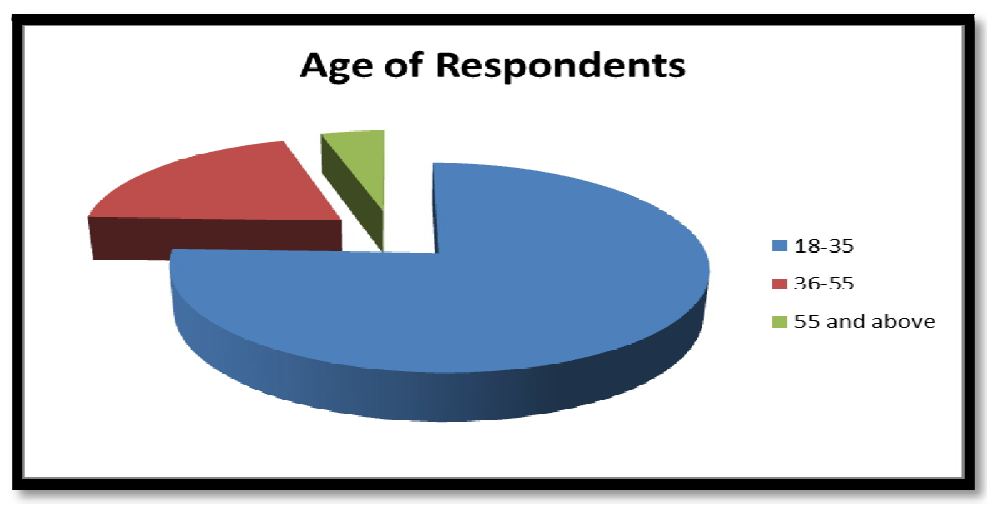

Figure 3: Age of the Respondents

Although more than 7.8 million (38.5 per cent) youth and adults in Kenya lacked the minimum literacy levels required to participate in national development, those who engaged in mobile money use had attained secondary education at $40.9 \%$ and post secondary education at 53\%. Education is crucial in operations and management of accounts as well as a basic understanding of the value-added capabilities of the mobile phone.

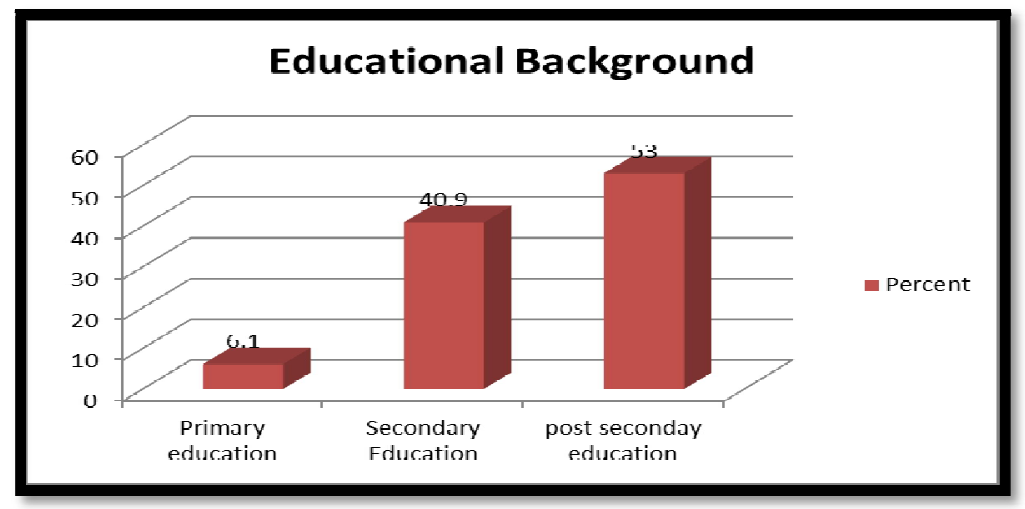

Figure 4: Respondents Educational Background 
This variable was necessary in establishing whether the level of income had an implication on mobile money use. A study by FSD Kenya (2015) established that mobile money was used for amounts that were less than Ksh 1,000 meaning that there existed a gap that needed to be addressed if mobile money was to be useful beyond P2P transactions. The monthly income of the respondents was fairly distributed with those earning less than Ksh 10,000 at 21.2\%, between 20,000 to 30,000 at 15 . \%, 40.9\% earning between 10,000 and $20,000,30,000$ to 40,000 at $12 \%$ and lastly above 50,000 at $33 \%$. This distribution was attributed to the fact that those interviewed were in the informal sector with diverse business activities.

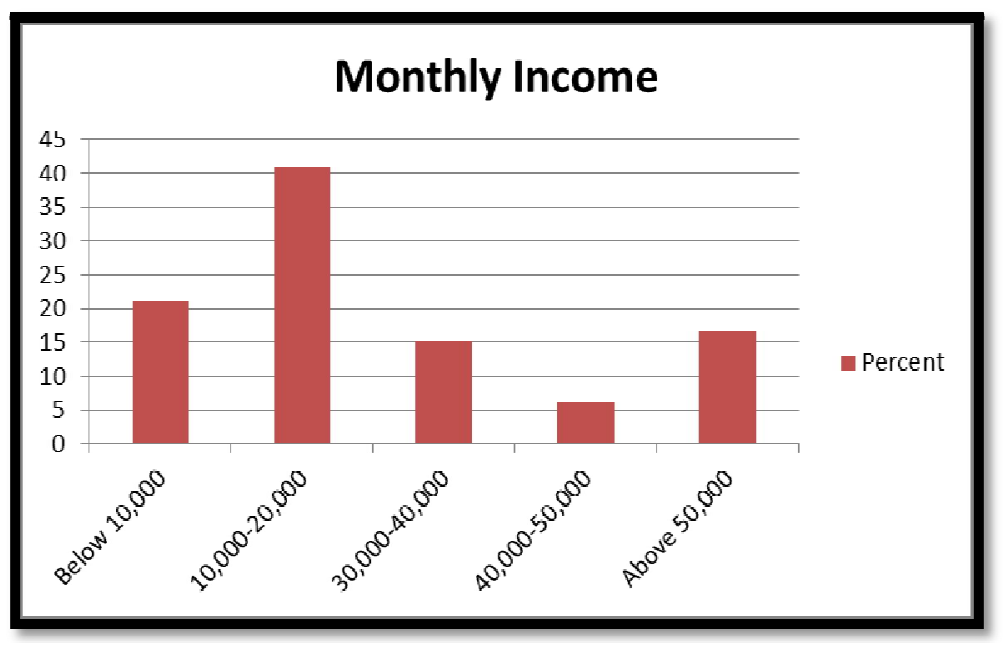

Figure 5: Monthly Income

While the study done by FSD identified monopoly as a major threat, this was evident in our study with those who used Safaricom for their transactions standing at $76 \%$. This was despite that fact that dual phones were available and money transfer was free particularly from airtel to any other number or in making payments. Equity also did not charge customers for making payments from the equital line and transferring money to an Equity account. All transactions in making payments from m-pesa were through Lipa na M-pesa where all transactions were charged and the charges increased with the amounts involved. However, Safaricom had a preserve tariff for members who wanted to make savings to M-shwari or KCB M-pesa of which in the two products Safaricom had interests. Customers were also not charged when they chose the option of buy goods on the Lipa na m-pesa menu, however merchants who were offering the service were charged for transferring the amounts accumulated in the pay bill to their bank accounts. Furthermore, buy goods cannot constitute financial inclusion because it is purely expenditure.

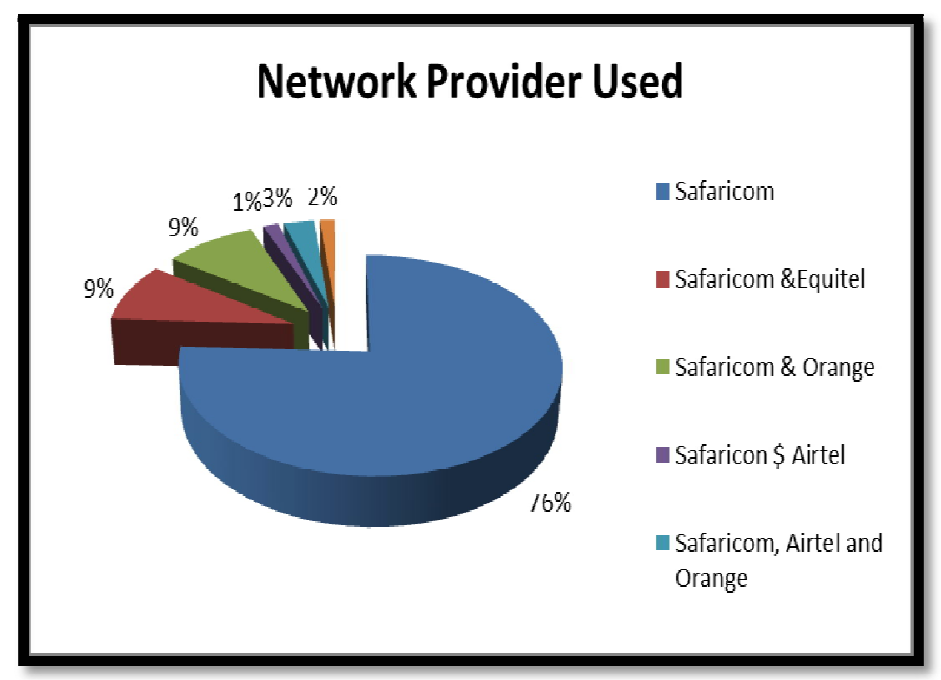

Figure 6: Mobile Network Operator Used

We were interested in establishing the relationships in the challenges of mobile money and the users themselves. While mobile money was well received and users did not doubt the gap it filled, majority at 35\% were frustrated by the inefficiency occasioned by shops that did not have enough electronic money to facilitate loading of user wallets, issues of trust were still a barrier to use of the services coming second at $26 \%$, cost of transaction came third at 18\%, and inability to transact, access to outlets and insecurity of funds tied at $7 \%$. 


\section{Challenges in Mobile Money Use}

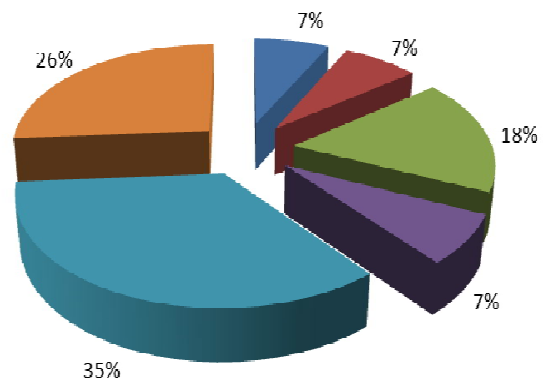

- Shops are Inefficient

- Insccurity of tunds

cost ot trinsinction

Access to Outlets

- Inability to transact

Du nul lrusl assislanils

Figure 7: Challenges in Mobile Money Use

\subsection{Cross Tabulations of Education, Challenges and Gender}

The cross tabulation of gender, education and challenges revealed that their existed a relationship in the level of education, gender of the respondent and the challenges they faced. All female respondents indicated that shops were in efficient and that it was difficult to access outlets. Cost of funds was also a barrier to use of mobile money among females who had attained both secondary and post secondary education. Inability to transact raised concerns and we were interested in understanding why this was so despite the levels of education for both gender and the responses gathered from the FGD confirmed that this was because the shops did not have float, others felt that the transaction cost was too high particularly when transferring huge sums of money and that sometimes transacting in an outlet depended on the assistant serving at the time

\begin{tabular}{|c|c|c|c|c|c|c|c|}
\hline \multicolumn{8}{|c|}{ Education*\$Challenges*Gender Cross tabulation } \\
\hline Gender & Education & Challenges & & & & & \\
\hline & & Inefficiency & Insecurity & Cost & Access & Inability & Trust \\
\hline Female & Secondary & & & & & & \\
\hline & & $100.00 \%$ & $0.00 \%$ & $50.00 \%$ & $100.00 \%$ & $33.30 \%$ & $16.70 \%$ \\
\hline & $\begin{array}{c}\text { post- } \\
\text { secondary }\end{array}$ & & & & & & \\
\hline & & $0.00 \%$ & $100.00 \%$ & $50.00 \%$ & $0.00 \%$ & $66.70 \%$ & $83.30 \%$ \\
\hline Male & Primary & & & & & & \\
\hline & & $0.00 \%$ & $0.00 \%$ & $20.00 \%$ & $0.00 \%$ & $0.00 \%$ & $16.70 \%$ \\
\hline & Secondary & & & & & & \\
\hline & & $50.00 \%$ & $0.00 \%$ & $40.00 \%$ & $50.00 \%$ & $55.60 \%$ & $50.00 \%$ \\
\hline & $\begin{array}{c}\text { post- } \\
\text { secondary }\end{array}$ & & & & & & \\
\hline & & $50.00 \%$ & $100.00 \%$ & $40.00 \%$ & $50.00 \%$ & $44.40 \%$ & $33.30 \%$ \\
\hline
\end{tabular}

.Table 1: Education, Challenges and Gender Cross Tabulation

\subsection{Monthly Income and Cost of Transaction}

The relationship as indicted in this cross tabulation between monthly income and cost of transaction posted insignificant values confirming that there existed a relationship between the amount of money one earned and the challenge of transaction cost. While the study collected user views overtime and the questionnaire was meant to triangulate the user experience with personal attributes, the comparisons confirmed that irrespective of the fact that these challenges were felt across gender, intervening factors of education level which enabled users to make informed decisions came to play. While it 
seems like those who had attained secondary and post-secondary education considered cost a challenge and those with less education did not consider it more of a barrier, the amount of money involved did play a role as less money attracted a lesser tariff. Again, insecurity of funds was cited by females with secondary education and males with post secondary education, the explanation for this was that it was easy to use money on the mobile wallet in unplanned ways with most of them saying that they used it all in purchase of credit and therefore they preferred keeping hard cash or avoiding to load their wallets altogether.

\begin{tabular}{|c|c|c|c|c|}
\hline \multicolumn{2}{|c|}{ Monthly Income } & Value & df & Asymp. Sig. (2-sided) \\
\hline \multirow{4}{*}{ Below 10,000 } & Pearson Chi-Square & $19.727^{b}$ & 2 & .000 \\
\hline & Likelihood Ratio & 14.344 & 2 & .001 \\
\hline & Linear-by-Linear Association & 10.049 & 1 & .002 \\
\hline & N of Valid Cases & 42 & & \\
\hline \multirow{4}{*}{$10,000-20,000$} & Pearson Chi-Square & $29.647 \mathrm{c}$ & 4 & .000 \\
\hline & Likelihood Ratio & 32.669 & 4 & .000 \\
\hline & Linear-by-Linear Association & 1.903 & 1 & .168 \\
\hline & N of Valid Cases & 81 & & \\
\hline \multirow{4}{*}{$30,000-40,000$} & Pearson Chi-Square & $5.000^{\mathrm{d}}$ & 2 & .082 \\
\hline & Likelihood Ratio & 7.110 & 2 & .029 \\
\hline & Linear-by-Linear Association & .439 & 1 & .507 \\
\hline & N of Valid Cases & 30 & & \\
\hline \multirow{4}{*}{$40,000-50,000$} & Pearson Chi-Square & $12.000^{\mathrm{e}}$ & 2 & .002 \\
\hline & Likelihood Ratio & 16.636 & 2 & .000 \\
\hline & Linear-by-Linear Association & 10.185 & 1 & .001 \\
\hline & N of Valid Cases & 12 & & \\
\hline \multirow{4}{*}{ Above 50,000} & Pearson Chi-Square & $33.000^{\mathrm{f}}$ & 2 & .000 \\
\hline & Likelihood Ratio & 20.106 & 2 & .000 \\
\hline & Linear-by-Linear Association & 1.829 & 1 & .176 \\
\hline & N of Valid Cases & 33 & & \\
\hline \multirow{4}{*}{ Total } & Pearson Chi-Square & $49.903^{\mathrm{a}}$ & 5 & .000 \\
\hline & Likelihood Ratio & 43.443 & 5 & .000 \\
\hline & Linear-by-Linear Association & .018 & 1 & .894 \\
\hline & N of Valid Cases & 198 & & \\
\hline
\end{tabular}

Table 2: Monthly Income and Cost of Transaction Chi-Square Tests

\subsection{Education, Gender and Trust}

The cross tabulation also indicates that there exists a significant relationship between the respondents' education level, their gender and the trust they have in the products. These findings confirm these three factors as cited in other studies (Kiiru 2007, FSD 2015). Education level is crucial in facilitating a critical analysis of models on offer as lack of it may predispose one to risks that require a critical eye. A product like M-shwari is popular among the lesser off segments in Kenya, the ease at which the disbursement is done and the amounts involved easily predisposes users to risk of missing the larger 
picture of the $7.5 \%$ per month which calculated per annum is $90 \%$ as well as being in a vicious cycle of debt. Consequently, lack of education may predispose one to gender based stereotypes leading to mistrust while critical analysis of a combination of factors will lead to a judgement based on perceived usefulness for those who have some basic education.

\begin{tabular}{|c|c|c|c|c|}
\hline \multicolumn{5}{|c|}{ Education*Gender* Trust } \\
\hline Chi-Square Tests & & & & \\
\hline $\begin{array}{l}\text { Educational } \\
\text { background }\end{array}$ & & Value & $\mathrm{df}$ & $\begin{array}{l}\text { Asymp. Sig. (2- } \\
\text { sided) }\end{array}$ \\
\hline \multirow[t]{2}{*}{ Primary education } & Pearson Chi-Square &. $\mathrm{b}$ & & \\
\hline & N of Valid Cases & 12 & & \\
\hline \multirow[t]{4}{*}{ Secondary Education } & Pearson Chi-Square & $29.244 \mathrm{c}$ & 5 & 0 \\
\hline & Likelihood Ratio & 24.338 & 5 & 0 \\
\hline & $\begin{array}{l}\text { Linear-by-Linear } \\
\text { Association }\end{array}$ & 0.677 & 1 & 0.411 \\
\hline & N of Valid Cases & 81 & & \\
\hline \multirow[t]{4}{*}{$\begin{array}{l}\text { post-secondary } \\
\text { education }\end{array}$} & Pearson Chi-Square & $21.758 d$ & 4 & 0 \\
\hline & Likelihood Ratio & 23.39 & 4 & 0 \\
\hline & $\begin{array}{l}\text { Linear-by-Linear } \\
\text { Association }\end{array}$ & 0.352 & 1 & 0.553 \\
\hline & N of Valid Cases & 105 & & \\
\hline \multirow[t]{4}{*}{ Total } & Pearson Chi-Square & $13.415 \mathrm{a}$ & 5 & 0.02 \\
\hline & Likelihood Ratio & 15.839 & 5 & 0.007 \\
\hline & $\begin{array}{l}\text { Linear-by-Linear } \\
\text { Association }\end{array}$ & 0.067 & 1 & 0.796 \\
\hline & N of Valid Cases & 198 & & \\
\hline
\end{tabular}

Table 3: Education, Gender and Trust Chi Square Tests

\subsection{Education Challenges and Age}

While those aged between 18-35 and 36-55 had attained primary school, education did not seem to be affected by the challenges those who had attained secondary and post-secondary education almost agreed that they experienced challenges cited. However, those above 55 years cited both in ability to transact and trust as their main challenges. These cross tabulation is key in technology adoption as it provides evidence to the fact that youth and middle aged are not skeptical when trying new technology and have no reason to mistrust assistants on the other hand those above 55 years may only have basic skills as far as mobile technology is concerned hindering them from participating usefully, in addition predisposition to old bank technology may also interfere with adoption when comparing the setting of outlets.

\section{Conclusion and Recommendations}

There is no doubt that mobile money provides a pathway for formalization of financial services among populations with a lower likelihood of formal inclusion who include the marginalized poor in urban areas and the poor as well as underserved in rural areas, women and youth. However, despite the expansion of financial infrastructure over the past ten years, access is still skewed (FinAccess, 2013). This Cleary indicates that mobile money use is more of an additive service to those already in the mainstream channels as opposed to transformative for the excluded populations. Findings point to the fact that is need for policy intervention by both the service providers and the regulator CAK in ensuring that challenges faced are mitigated for effective uptake and use. 
Nurturing savings in order to encourage responsibility as well as afford users planned as well as affordable credit may be the solution to reaching out to the unreached in society. Mobile money as it is offered only benefits the institutions that offer the services as revealed in the study. Access tariffs have no consideration of type of product and a blanket tariff is availed to the users. If lesser off segments are to benefit through mobile money then a deliberate effort to cushion them from access tariffs need to be instituted. A saving culture can only be nurtured by enabling savers to free of charge transfer money to their savings accounts. While products offered by MNOs have zero tariffs on savings, for some reason they miss on the point when they engage with third party providers of similar products with a risk of users losing more than they may gain and serve only to enrich the already rich service providers.

There is need for MNO players to form partnerships with added value third party models mostly ASCAs and ROSCAs that reach the unreached in society in order to extend affordable and friendly services to targeted segments. Furthermore, ASCAs and ROSCAs provide the discipline necessary for financial management and rarely just concentrate on access to credit but are also concerned with the welfare of the entire household; combining services like insurance, markets for goods and services and education which are key in sustaining livelihoods.

This study therefore recommends that Mobile Network Providers be compelled to avail the savings tariff which is currently a preserve of their own products (M-shwari, KCB m-pesa) to third party platforms whose aim is to nurture a savings culture among the financially excluded. There is also need to differentiate those making payments from those making savings. In addition, mobile network providers need to forge partnerships with the informal groups to help them remain simplistic devoid of extra expenses while the main legal requirements are met by the partnering MNO. These partnerships will help in streamlining operations and ensure prudent management of group funds as well as create trust among users through joint awareness campaigns.

Consequently, banks and MNOs need to establish a strategy of empowering agents to serve their customers efficiently. The model of financing agents over the weekends by safari com needs to be streamlined and extended through out to agents as long as there is accountability. Banks and the other MNOs could also initiate a similar strategy to avoid frustration experienced by users when they cannot be served because agents do not have enough electronic money. Service providers also need to protect customers from losing money to fraudsters by first cleaning their database of fraudulent registrations. This can be actualized through partnerships with the registrar of persons as it will be easy to trace all transactions to a valid identity. Currently MNOs do not follow up lost money through mobile money transactions on a customer's behalf choosing to direct such victims to the police who rarely give any fruitful assistance. Cases of dishonest staff who disclose customer information should be dealt with by conducting refresher courses on professional ethics and integrity as well as meting severe punishment on culpable employees to deter others from engaging in the vice.

ROSCAs and ASCAs should facilitate training programs for their members to enable them make informed choices as far as availed products are concerned, However the Government should stick to its goal of ensuring $50 \%$ literacy levels by 2030. This effort will eventually empower users with the knowledge required for effective management of individual financial affairs. In addition, besides savings and credit ROSCAs and ASCAs should research on viable business opportunities that they can recommend to members in order for them to realize good profit margins, foster growth and also reduce chances of defaulting on loans.

Beyond mobile money use and the growth of ROSCAs and ASCAs, there should be a deliberate effort by the government to provide an enabling environment for growth of entrepreneurship in marginalized and rural areas by deliberately instituting demand for goods from these areas. By so doing goods and services emanating from activities realized through the added value mobile money use will go beyond marginal profits to allow repayment of credit as well as development economically and socially.

\section{References}

i. Adams, D and von Pischke, J D (1992). Microenterprise credit programs: 'deja vu', World Development 20, 1463-1470

ii. CCK (2014). Quarterly sector Statistics Report, Second Quarter of the Financial Year 2013/ 2914 (Oct-DEC 2013). Available at www.cck.go.ke/

iii. Central Bank of Kenya (CBK) and FSD Kenya (2007). Financial Access in Kenya: Results of the 2006 national survey, Nairobi (available at http:// fsdkenya.org/ publication/ financial-access-in-kenya-results-of-the-2006-national-survey/ ).

iv. CGAP (2013). Micro finance and mobile banking: Burring lines. Available at www.cgap.org.

v. CGAP (2015). Fixing the Hidden Charges in Lipan a M-pesa/ CGAP available at www.cgap.org

vi. Davis, F. D. (1989). Perceived usefulness, perceived ease of use, and user acceptance of information technology. MIS Quarterly, 13(3), 319-339.

vii. Dr. Martina Mulwa \& Dr. Ndeti Ndati (2013). Network Logic and The Stabilization Of Mobile Banking Products A Case Study Of Selected Mobile Banking Products In Kenya. International Journal of Innovative Research \& Development. www.ijird.com August, 2013 Vol 2 Issue 8

viii. FinAccess National Survey (2013). Profiling Developments in Financial Access and Usage inKenya. Available at www. fsdkenya.org-/ fin access 13 results_analysis.pdf.

ix. Frankline Sunday (2015). Consumers lose out as Safaricom and equity tariff wars intensify; equity accuses Safaricom of raising rates charged to its consumers when transferring cash to m-pesa accounts. Available at www.ipsos.co.ke/ newbase exports pdf 
x. FSD ( 2015). Kenya's Financial Transformation in the 21st Century, Nairobi Kenya. www.fsdkenya,org

xi. FSD Kenya (2009). The Role of Informal Financial Groups in Extending Access in Kenya. Available at www. Fsdkenya.org

xii. Godoe, P. \& Johansen, T.S., (2012). Understanding adoption of new technologies: Technology readiness and technology acceptance as an integrated concept. Journal of European Psychology Students. 3(1), pp.38-52. DOI: http:/ / doi.org/ 10.5334/ jeps.aq

xiii. Gulli, H. (1998). Microfinance and Poverty: Questioning the Conventional Wisdom, Washington, DC, Inter-American Development Bank.

xiv. InterMedia (2015), Financial inclusion insights tracker survey Kenya 2014, Washington, DC (available at www.finclusion.org).

xv. King, M. (2012), "Is Mobile Banking Breaking the Tyranny of Distance to Bank Infrastructure? Evidence from Kenya”, IIIS Discussion Paper No.412, Dublin.

xvi. Martina Mulwa (2012). The Role of Wireless Communication in Financial Inclusion. A Case Study of Selected Mobile Banking Products in Makueni County. A Dissertation Submitted at the School of Journalism and Mass Communication University of Nairobi. URL:erepository.uonbi.ac.ke/ handle/ 11295/ 8457

xvii. Parasuraman, A. (2000). Technology readiness index (TRI): a multiple-item scale to measure readiness to embrace new technologies. Journal of Service Research, 2(4), 307-320.

xviii. Parasuraman, A., \& Colby, C. L. (2001). Techno-ready marketing: how and why your customers adopt technology. New York: The Free Press.

xix. Vincent Matinde (2014). Mobile Money fraud on the rise in Kenya. Available at www.itwebafrica.com/security515Kenya.

xx. Zollman, J. (2014). The Kenya Financial Diaries: Executive summary. Nairobi, Kenya: FSD Kenya. 